\title{
THE PARTICIPATION OF WOMEN IN POLITICS. DELIBERATIONS ON THE GENDER PARITY BILL
}

\author{
by Joanna Marszałek-Kawa \\ The equality of people and the sense of justice require equal rights \\ for women. Those who do not understand it need education rather \\ than evidence.
}

Leon Petrażycki, 1906

Male politicians are becoming increasingly aware of the fact that women have great power. Girls account for $50 \%$ of the population of school students. Women seem to be much better at handling the financial crisis than men. The recession primarily affected the masculine part of business widespread layoffs hit typically male industries, such as cars, tobacco, financial services. In the U.S. , men account for $80 \%$ of people who lost jobs as the result of the recent crisis. ${ }^{1}$

Moreover, it is women that make most decisions relating to household expenses. They are also more inclined to save up for future. They typically spend money on things like education, healthcare, food and cosmetics. They also invest in their children's future. At present, women have about

\footnotetext{
1 R. Foroohar, S.H. Greenberg, Gotowe na wszystko, "Newsweek" (Polish ed.), October 4, 2009, p. 65.
} 
$\$ 10.5$ trillion at their disposal, while men have approximately $\$ 23.4$ trillion. However, this disproportion is still getting smaller. The past decade saw the distance between these two worlds constantly diminish. Women control $\$ 12$ trillion out of $\$ 18.4$ trillion spent by consumers every year. Moreover, the increasing number of working women - as Michael J. Silverstein points - means that their income is increasing. They often earn more than men. The generation of women that accepted lower pay than their male counterparts is now in their retirement age. If this trend persists, in ten years' time one hundred out of five hundred multinational corporations will be headed by women. ${ }^{2}$

FIGURE 1. What is women's share in the decisions concerning household expenses?

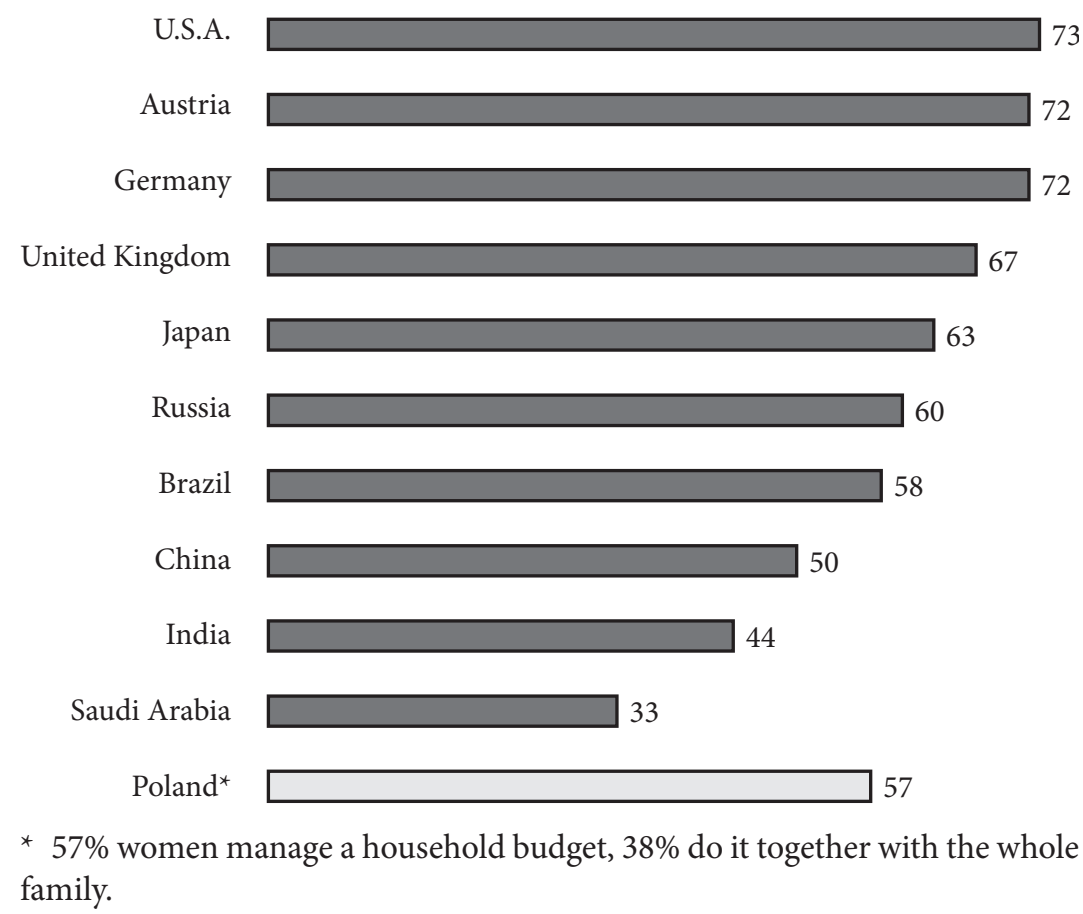

\footnotetext{
2 Ibidem, p. 65.
} 
As the research done by Boston Consulting Group (BCG) shows, women are quite likely to take over the lead of the global economy after the recession comes to an end. This is also confirmed by the data in the figure below.

FIGURE 2. Women on company boards

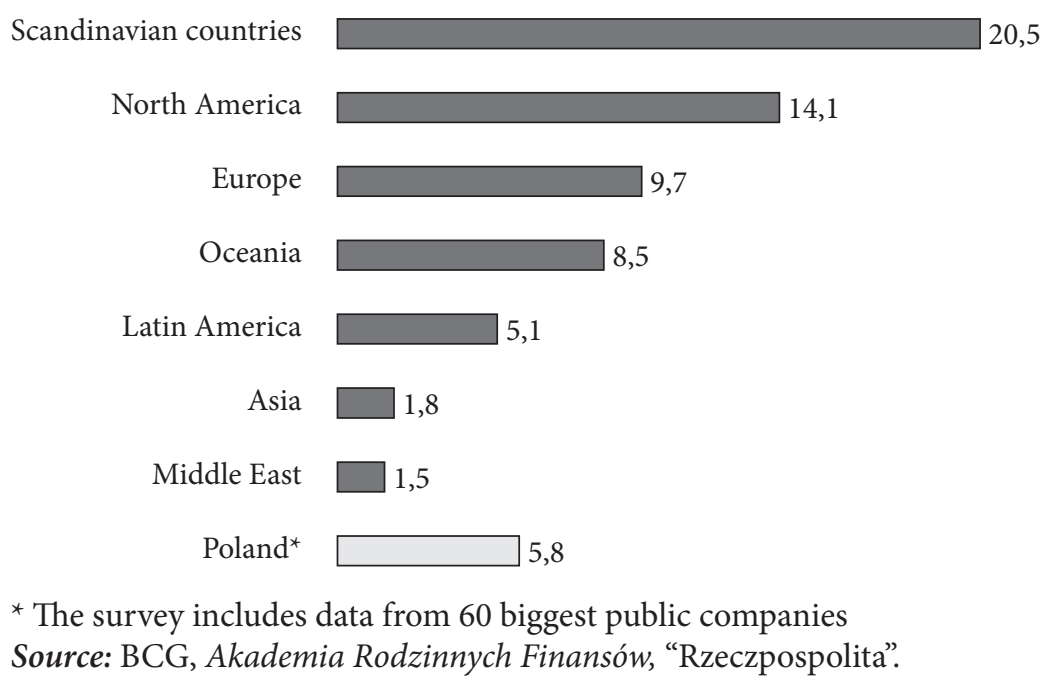

When women decide to go into politics, not only do they contribute content-related arguments to public discourse, but they also present a lot more balanced and subtle approach to debate. They work intensively on bills connected with education, healthcare, tax reform and social politics. They are likely to designate bigger amounts of public money to the poor, e.g. by introducing a family tax relief. Women are usually better prepared for their tasks; they are generally more insightful and responsible. They also do not care about fame and glory.

In Poland, the issue of gender parity quite regularly appears every time the public opinion loses interest in yet another political scandal.

Gender parity is understood as an order in which both sexes share the same number of representatives in decision-making bodies. It is regulated by law in the form of so called quota systems - hiring and admission policies requiring that a specified number or percentage of certain social groups be hired or admitted - in this particular case they specify that men 
The participation of women in politics. Deliberations on the gender parity bill... 85

and women have an equal status and neither sex should prevail in public offices.

The literature on the subject indicates that gender parity has one fundamental purpose. It aims at decreasing, or even eliminating, the existing differences and inequalities both within decision-making bodies and in other areas of public life, e.g. access to the labour market.

The data provided by the United Nations Economic and Social Council show that even a $30 \%$ participation in the legislative power gives a particular social group real influence on political decisions. ${ }^{3}$

Thus, the gender which has been underrepresented so far is now privileged. However, this will certainly not solve the problem as it is women themselves that have to change. They should start voting for women and stop preferring men as their bosses.

As Magdalena Środa points, when the Greek parliament passed a new law, which was intended to introduce a more equal distribution of places on electoral lists, the fundamental question women asked men was: Don't you feel humiliated by the fact that you are members of parliament only because you are men? Indeed, it is a serious problem, which seems to be recognized mostly by women's organizations fighting for equal rights. ${ }^{4}$

Gender parity, in the form of an electoral quota system, was first introduced in Europe as early as in the 1970s in Norway by the Socialist Left Party and the Liberal Party. ${ }^{5}$ Its principal aim was to make the number of women and men in politics equal not later than in the mid-1980s. Since then women have constituted at least $40 \%$ of each new Norwegian government. In France, obligatory gender parity was introduced in 2000 - at present, women have the right to $50 \%$ of places on electoral lists and their names are positioned with men's names alternately. In Spain, in turn, the act of equal status of women and men establishes an electoral quota system, in accordance with which the number of candidates of one sex cannot be lower than $40 \%$ and higher than $60 \%$. There is also gender parity in Sweden, Iceland and Belgium.

\footnotetext{
3 www.polskajestkobieta.org, Marta Marska, October 6, 2009.

4 M. Środa, Parytety, parytety, "Newsweek" (Polish ed.), supplement "Kobieta”, November 1, 2009.

5 www.polskajestkobieta.pl, Marta Marska, October 10, 2009.
} 
In Greece, at the beginning of this century, in compliance with article 116.2 the number of women and men on electoral lists must be equal. The lists that do not meet this requirement cannot be registered. Slovenia also has a quota system. At least $40 \%$ of candidates on electoral lists to the European Parliament must be women. After this regulation was introduced, women accounted for $42.9 \%$ of the European Parliament members from Slovenia. In Denmark, all councils, commissions and committees in the public sector must include an equal number of men and women - the composition of these bodies is approved by the Minister for Employment and Gender Equality, who is responsible for guarding parities. In Finland, women must constitute at least $40 \%$ of the membership of government, advisory and municipal institutions. Germany, in turn, as early as in 1994 introduced a law, according to which all appointing bodies are obliged to put forward candidates of both sexes for a given position. ${ }^{6}$

The European Union has also introduced a number of law regulations, which aim at ensuring the equality of both genders in the public sphere. They include:

- Council Directive 75/117/EEC on equal pay - this directive forbids discrimination on the grounds of gender. The same job deserves equal remuneration,

- Council Directive 76/207/EEC on equal treatment as regards access to employment, vocational training and promo,

- Council Directive 2002/73/EC defines some forms of sexual harassment as sexual discrimination. ${ }^{7}$

It must also be mentioned that gender parity solutions are not only specific to Europe. In Ruanda, for example, women account for 56\% of MPs, the principal reason for which is the fact that a quota system is applied not only to electoral lists, but also to the principles of filling the posts at public offices. ${ }^{8}$

6 www.krytykapolityczna.pl, K. Dunin, M. Środa, July 13, 2009.

7 E. Zielińska, Przeciwdziałanie barierom awansu kobiet w prawie Unii Europejskiej, [in:] Szklany sufit. Bariery i ograniczenia karier kobiet. Monografia zjawiska, ed. A. Titkow, Warszawa 2003, pp. 337-338.

8 A. Grabau, Parytet niejedno ma imię, "Przegląd”, February 28, 2010, p. 33. 
The participation of women in politics. Deliberations on the gender parity bill... 87

Prof. Małgorzata Fuszara points that a constitutional duty of having the right proportion of women and men on electoral lists currently exists in 45 countries of the world. In Europe, quota systems regarding lists of candidates are in force in a number of countries, from Belgium to Macedonia. "A lot of quota systems include the obligation of placing names of men and women alternately on lists, sometimes at least every third candidate must be a woman."9

It is commonly believed, however, that women will play a significant role in politics only if they start supporting each other and all the differences and tensions between competing women's organizations are eliminated. This will happen when women understand that only solidarity and loyalty can help them achieve long-term success.

The present reality in Poland is not bright in this respect. For example, Henryka Bochniarz, a candidate for the President of Poland in 2005, did not receive any major support from women's organization although she had hoped for it. Bochniarz also claims that a Polish female politician has to get rid of her feminine characteristics, which can be perceived as weaknesses in the eyes of public opinion. It is not well received by voters when a female politician talks about her family. On the other hand, if male candidates are accompanied by their wives and children in their campaigns, it certainly works in their favour. ${ }^{10}$ Prof. Teresa Sasińska-Klas, a sociologist from the Jagiellonian University, argues that the achievements of many women in politics tend to be underrated. ${ }^{11}$ It is a really serious problem, indeed, which has its source in the way in which the role of a woman is stereotypically perceived in the society.

According to Magdalena Środa, who was one of the initiators of the Congress of Polish Women held in June 2009, it is a myth that women do not want to go into politics. They simply feel excluded by party leaders, who prepare party lists. ${ }^{12}$

Katarzyna Piekarska from SLD (Democratic Left Alliance) disagrees with a common view that democracy without women's participation is

\footnotetext{
9 www.iwoman.pl, see also: M. Fuszara, Kobiety w polityce, Warszawa 2007.

10 www.wiadomości.gazeta.pl, August 2, 2005.

11 www.wiadomości.gazeta.pl, August 2, 2005.

12 www.wyborcza.pl, August 17, 2009.
} 
actually semi-democracy. She believes that democracy without women means there is no democracy. ${ }^{13}$

In Poland, women typically represent $20 \%$ of the composition of Parliament and female politicians are usually better educated than their male colleagues. In Sweden, there are twice as many women in Parliament, but in the Czech Republic their number is 5\% lower.

Polish women were granted suffrage over 90 years ago, on November $28,1918^{14}$ The Governor of the State issued a decree on the electoral law to the Legislative Sejm (the Polish parliament).

It specified that "each citizen of Poland, irrespective of their sex, has the right to vote in elections to the Sejm". As Kazimiera Szczuka notes, "Poland was in the vanguard of Europe." 15 Before the Second World War, women constituted only $2 \%$ of the composition of the Sejm, and $4 \%$ of the Senate. In the People's Republic of Poland the percentage of women in the Sejm was quite high, although there were no parities in the law. For example, between 1980 and 1985 (the eighth term of office of the Sejm) women occupied $23 \%$ of seats in the chamber. Joanna Cieśla notes that "the more ornamental was the function of Parliament in the People's Republic of Poland, the fewer women were its members - in 1956 only $4 \%$ of the Sejm deputies were women." 16 After the political transformation, 62 women received seats in the "contract" Sejm, whereas 7 women became senators. In the first term of office of the Sejm women got $9.5 \%$ of seats. In the second and the third term of office, the percentage grew to $13 \%$. As it was mentioned before, the figures have not changed substantially since the fourth term as the female representation in Parliament equals to $20.4 \% .{ }^{17}$ At present, every fifth deputy is a woman - there are 92 women in the Sejm, and only eight in the Senate. Only two women chair parliamentary committees. Each party in Parliament has approximately 20\% female members.

\footnotetext{
13 www.wordpress.com, October 25, 2008.

14 For more details see: E. Lisowska, Równouprawnienie kobiet i mężczyzn w społeczeństwie, Warszawa 2008, pp. 210-211.

15 www.partnerstwo.onet.pl.

16 J. Cieśla, Trudne równanie, “Polityka”, No. 35, August 29, 2009, p. 19.

17 E. Lisowska, Równouprawnienie kobiet i mężczyzn..., pp. 212-214.
} 
The figure below shows the composition of the Polish Sejm in terms of women's participation since 1991. It should also be indicated that the figures for the Polish Senate are similarly unimpressive. ${ }^{18}$

FIGURE 3. The Polish Sejm in the years 1991-2008 (in \%).

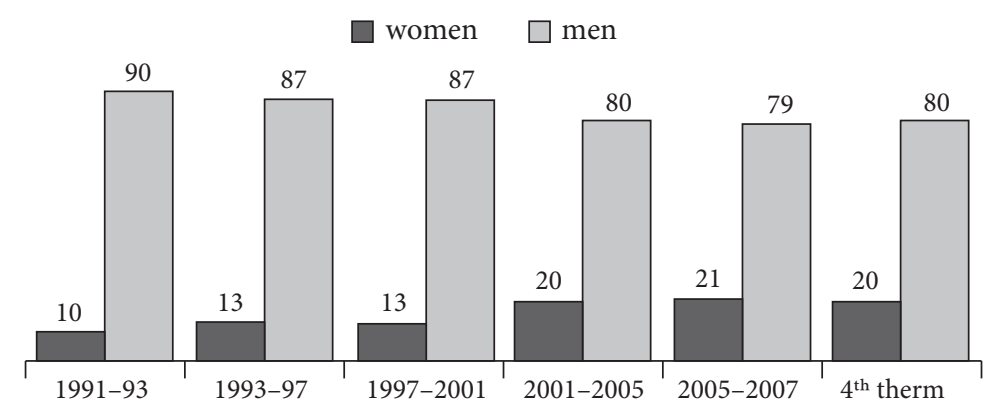

Source: A. Franowska, www.iwoman.pl, January 27, 2009.

FIGURE 4. The number of women in the European Parliament in relation to the number of seats.

\begin{tabular}{|l|c|c|}
\hline Country & $\begin{array}{c}\text { The number of } \\
\text { women in the } \\
\text { European Parliament }\end{array}$ & $\begin{array}{c}\text { The percentage of } \\
\text { women (\%) }\end{array}$ \\
\hline Sweden & 11 & 57,89 \\
\hline Lithuania & 6 & 46,15 \\
\hline The Netherlands & 12 & 44,44 \\
\hline France & 34 & 43,59 \\
\hline Slovenia & 3 & 42,86 \\
\hline Austria & 7 & 38,46 \\
\hline Ireland & 5 & 35,71 \\
\hline Denmark & 5 & 35,71 \\
\hline Finland & 5 & 35,71 \\
\hline Slovakia & 5 & 35,71 \\
\hline Estonia & 2 & 33,33 \\
\hline
\end{tabular}

18 www.iwoman.pl, October 6, 2009. 


\begin{tabular}{|l|c|c|}
\hline Country & $\begin{array}{c}\text { The number of } \\
\text { women in the } \\
\text { European Parliament }\end{array}$ & $\begin{array}{c}\text { The percentage of } \\
\text { women (\%) }\end{array}$ \\
\hline Spain & 17 & 31,48 \\
\hline Germany & 31 & 31,31 \\
\hline Belgium & 7 & 29,17 \\
\hline Greece & 7 & 29,17 \\
\hline Hungary & 7 & 27,17 \\
\hline Portugal & 6 & 25,00 \\
\hline The United Kingdom & 18 & 23,08 \\
\hline Italy & 16 & 20,51 \\
\hline The Czech Republic & 5 & 20,83 \\
\hline Luxembourg & 1 & 16,67 \\
\hline Poland & 7 & 12,96 \\
\hline Cyprus & 0 & 0,00 \\
\hline Malta & 218 & 0,00 \\
\hline TOTAL & & 29,78 \\
\hline
\end{tabular}

Source: A. Franowska, www.iwoman.pl, January 27, 2009.

Women are beginning to play an increasingly important role in world politics, they become chancellors, ministers and diplomats. Examples are evident in France, Spain and Germany. In the history of the Third Republic of Poland (after 1989) only one woman - Hanna Suchocka - held the post of Prime Minister so far. Only two women - Hanna GronkiewiczWaltz and Henryka Bochniarz - ran in presidential elections.

Nevertheless, it is worth mentioning that the problem of female representation in decision making bodies exists in the whole democratic world. A. Frankowska notes that there are only twenty countries in which women have higher than 30\% participation in legislatures. Within this group, only eight countries are the European Union members. $47 \%$ of seats in the Riksdag are held by women. Similarly, large numbers of women are MPs in Finland, the Netherlands, Denmark, Spain, Belgium, Germany, and Austria. In as many as seven European Union member states female politicians do not reach a level of $7 \%$ representation in the legislatures - 
these are the Czech Republic, Cyprus, Ireland, Slovenia, Hungary, Romania, and Malta. ${ }^{19}$

Public opinion polls also confirm that new regulations, which will ensure equal participation of women and men in exercising power, should be introduced as soon as possible. $70 \%$ of the men surveyed said that the current law in Poland guarantees equal treatment of both sexes, while a lot fewer women are happy with the present situation. Only $56 \%$ of the female respondents believe that the Polish law ensures that their status is equal to men's.

FIGURE 5. Do you think that the current law in Poland sufficiently guarantees equal status of men and women?

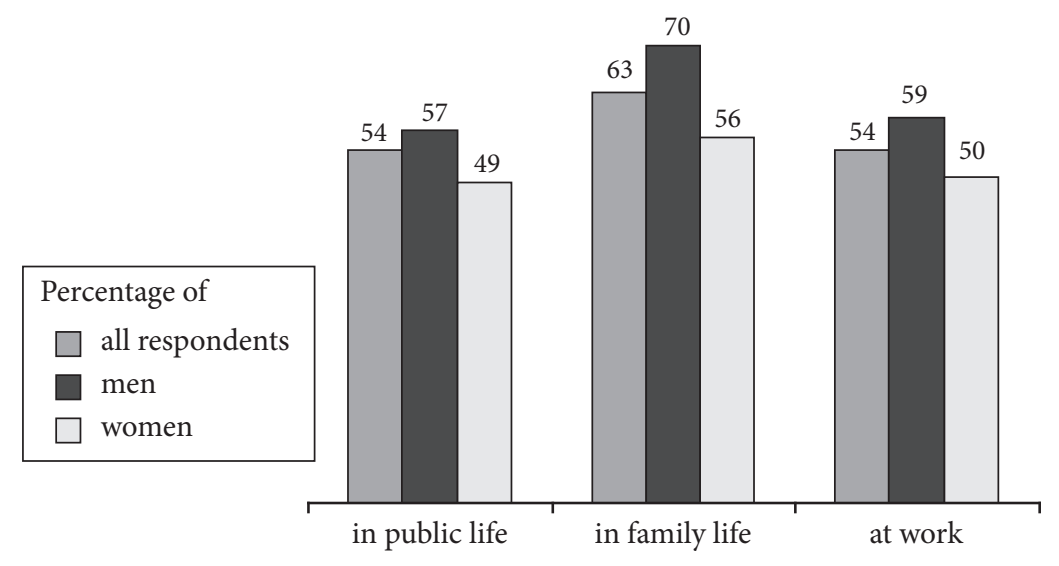

Source: Public Opinion Research Centre (CBOS).

On June 20-22, 2009, on the initiative of Jolanta Kwaśniewska, Henryka Bochniarz, prof. Magdalena Środa, Barbra Labuda and Danuta Hubner, the conference on the occasion of twenty years of transformation 1989-2009 was held. It was attended by a few thousands women representing many different environments from the whole country. The organizers of the Congress of Polish Women emphasized that "thanks to their hard work and activity, women had significant contribution to the process of transformation. The initiators of the Congress intended to present

19 A. Frankowska, www.iwoman.pl, January 29, 2009. 
women's commitment by indicating their most important achievements in the economic life of the country, in science, culture, politics, in mass media, and in everyday life. As the organizers put it - We want to look at the development of Poland and its achievements from the perspective of women, who constitute - which is often overlooked - more than a half of all citizens. We also wish to define the most serious problems connected with the status and rights of women, identify the barriers which are sources of explicit and hidden disparities in the status of women and men."20

The Congress reached a conclusion that electoral lists should be prepared on the principle of gender parity and the appropriate changes in law should be prepared. It also emphasized the need for establishing an independent office of the Ombudsman for Women and Equality. Following the conclusions of the Congress, the citizens' bill of gender parity was drawn up. It was signed by 154,000 women and men.

It should be mentioned here that the current gender parity bill is not the first one in Poland. As early as in 2001, the Vice-Speaker of the Polish parliament, Olga Krzyżanowska, was in charge of the team working on a similar bill. However, the bill was lost in the first reading. All subsequent proposals suffered the same fate.

When indicating the need for introducing gender parity in the Polish electoral law, the participants of the Congress of Polish Women presented the following ten arguments: ${ }^{21}$

1. As gender parities give equal opportunities to women and men in elections, they are one of the basic mechanisms of democracy. Parities accelerate the process of equal participation, which is one of the most important goals of democracy. They also realize the constitutional principle of the equality of women and men.

2. Quota systems have been introduced in $45 \%$ of the countries in the world. A quota system led to an increase of the percentage of women in Parliament from 11\% to 37\%. In France, thanks to the introduction of

20 www.magazyn.kreatura.net, G. Latos, M. Chińcz, The Congress of Polish Women, June 21, 2009.

21 J. Paradowska, Panie prosza panów, “Polityka”, No. 33, August 15, 2009, p.12. 
The participation of women in politics. Deliberations on the gender parity bill... 93

quotas in the municipal elections of 2001, the number of women in local governments grew twofold.

3. Gender parities are gaining increasing support of Polish voters, irrespective of their political beliefs: as many as $60 \%$ of the respondents are in favour of parities.

4. Gender parities on electoral lists may turn out to be a chief asset of the Polish Presidency in the EU. The European Union, from the Treaty of Rome to the Treaty of Lisbon, has always attached immense attention to the issues of gender equality and preventing discrimination. Poland focused on the economic transformation and did not take enough care of the problems of disparities between sexes. If Poland introduces gender parities, it will be able to promote this significant achievement in the area of equality.

5. Gender parities offer the opportunity to upgrade the quality of Polish politics. Equality is not only fair, but also profitable. Women are different, they view the world and its problems differently, and they have a different approach to negotiating and handling conflicts. Women can change and enrich politics. Research shows that $73 \%$ of Poles believe women will attach much more attention to social issues, $62 \%$ of them think that thanks to women politics will be more focused on real, everyday problems, and $54 \%$ of the respondents expect that the increased participation of women in politics will lead to a decrease in the number of conflicts and will increase the level of honesty. What will really happen? The only way to find out is to introduce parities.

6. As gender parities differentiate a pool of candidates, they reinforce the primary rule of democracy - the freedom of choice. Thanks to parities, citizens will be able to choose candidates from among women and men - not predominantly men, as it has been the case so far. $66 \%$ of Poles believe that gender parity will encourage women to take part in politics the field they have felt excluded from. 56\% of the respondents declare they will vote for a woman.

7. Gender parities are politically neutral, they do not serve any particular purposes, political programmes or parties. Their function is purely formal, it serves the real equality of women and men in all political options. Parities are the same element of democracy as establishing the 
age qualification in elections, the number and structure of constituencies or the tripartite division of powers. Gender parity is as an "artificial" tool as the whole democracy, which is constantly changing and developing.

8. Gender parities are an important instrument of justice. For hundreds of years women had no voting rights. When they were finally granted suffrage, long-standing tradition and practices, which excluded them from the public sphere, hampered their active participation in politics, where a gender (male) was traditionally a chief asset. It has been evident both on electoral lists and in the composition of the most important decision making bodies in Poland. The situation will change only if we introduce gender parity, which will abolish the actual discrimination of one of the sexes.

9. Gender parities do not offer any privileges. They only give a chance for women to be elected. It is voters, not parities that decide on the distribution of seats. So far, gender has played a decisive role in the preparation of electoral lists - men were much more likely to be placed on them. As parities introduce a specified proportion of men and women, party leaders will try to find politically efficient women, who up to now have not had big chances of making names for themselves in a typically male party environment.

10. Gender parities prevent the political discrimination of women, thanks to which they strengthen their sense of responsibility for the political community they belong to. Women are said to be "the neck that turns the head," which means that their power - although informal - is great. Thus, it is high time they took responsibility for the political life and decision processes in the country which declares that all its citizens are equal. There is no responsibility without real equality. ${ }^{22}$

Prof. Małgorzata Fuszara emphasizes that the contemporary "quota systems are the most effective means of increasing women's participation in positions of authority as the lists which do not meet these criteria are not registered. There are also countries, such as France, which impose harsh financial penalties on the parties which disobey the principle of

22 www.kongreskobiet.pl. 
The participation of women in politics. Deliberations on the gender parity bill... 95

equal gender distribution on their lists of candidates." ${ }^{23}$ Fuszara also indicates that "quota systems force party leaders to adopt a more open attitude to women and evaluate them in terms of their competencies."24

Prof. Magdalena Środa uses even stronger words as she claims that "a woman who pursues a career in big business or politics is still an anomaly." 25 In the world of male politics, it is quite commonly believed that intelligent women are a rare breed. ${ }^{26}$

The results of a survey carried out in July 2009, just after the Congress of Polish Women, show that $61 \%$ of the respondents are in favour of the idea of the principle of 50:50 gender parity in the elections to the Sejm, the European Parliament and local governments. 27\% of the people under survey were against. These results are quite satisfactory and they show that Polish voters are aware of the problem of the underrepresentation of women in politics. ${ }^{27} \mathrm{~A}$ recent poll performed in January 2010 by the Public Opinion Research Centre (CBOS) confirms that $60 \%$ of Polish citizens are in favour of the idea of gender parities on electoral lists. It must be emphasized, however, that quite a large number of female politicians, including many MPs, are quite critical of the principles of the new bill.

TABLE 1. Female MPs on gender parity.

\begin{tabular}{|l|c|c|c|}
\hline & $\begin{array}{c}\text { Citizens' Platform } \\
(\text { PO) }\end{array}$ & $\begin{array}{c}\text { Law and Justice } \\
\text { (PiS) }\end{array}$ & Left \\
\hline Total & 47 & 38 & 6 \\
\hline
\end{tabular}

23 www.iwoman.pl, October 6, 2009.

24 J. Cieśla, Trudne równanie..., p. 19.

25 M. Środa, Parytety, parytety..., p. 12.

26 G. Łakomski, Zdarzają się inteligentne kobiety, an interview with J. Korwin-Mikke, "Wprost", March 14, 2010, p. 32.

27 At the Congress of Polish Women, in June 2009, the principles of a new citizens' bill were laid off. The bill concerned "changing the law: the act of the electoral law to the Sejm, district councils, county councils and regional councils, and the act of the electoral law to the European Parliament, with regard to the introduction of gender parity on electoral lists." The bill proposes 50:50 parity on electoral lists for both sexes. However, if the number of candidates on a list is odd, e.g. 17, women should receive 9 seats. If the principle of gender parity is not obeyed, the list will fail to be registered by the appropriate electoral commission. 


\begin{tabular}{|l|c|c|c|}
\hline & $\begin{array}{c}\text { Citizens' Platform } \\
(\text { PO) }\end{array}$ & $\begin{array}{c}\text { Law and Justice } \\
(\mathrm{PiS})\end{array}$ & Left \\
\hline Surveyed & 38 & 24 & 5 \\
\hline Against & 32 & 24 & 0 \\
\hline For & 6 & 0 & 5 \\
\hline
\end{tabular}

The survey was carried out among 67 out of 87 women deputies from the three biggest party groups in the Sejm.

Source: A. Sijka, Seksmisja bez protezy, "Wprost”, March 14, 2010, p. 22.

Female deputies believe that there are not enough women willing to get involved in politics. They argue that the introduction of gender parity will result in the names of office workers or secretaries being placed on the lists of candidates. ${ }^{28}$

It also must be mentioned that there are some arguments that the new bill, which proposes the constitutional guarantee of half the places on electoral lists for women, is not in accordance with the fundamental law. A large number of constitutional experts recognized that gender parities do not contravene the constitutional principle of equality, and, what is more, they serve the purpose of expressing it more fully through establishing solutions, which foster this principle. This opinion is shared by acknowledged professors, such as Roman Wieruszewski, Wiktor Osiatyński, Wojciech Sadurski, Piotr Winczorek, as well as Artur Bodnar, Ph.D. and the President of the European Parliament, Jerzy Buzek. Moreover, they point that solutions of this kind have been adopted in 45 countries of the world. Prof. Wiktor Osiatyński believes that "the introduction of gender parities on electoral lists will help to fulfil the constitutional norms, especially the ones included in articles 32 and 33 of the Constitution." Prof. Wieruszyński, in turn, indicates that by introducing a parity solution, Poland "would act in accordance with the recommendations of the Convention on the Elimination of All Forms of Discrimination, which was accepted by Poland in 1980. Article 4 of the Convention defines temporary special measures which might be taken in order to accelerate de facto equality between men and women. Quota systems, including parities, are

\footnotetext{
28 J. Cieśla, Trudne równanie..., p. 35.
} 
The participation of women in politics. Deliberations on the gender parity bill... 97

one of such solutions."29 Prof. Winczorek notes that "the principle of equality is now infringed, we can observe disparity in de facto status of women and men. The violators are those who prepare lists of candidates in general elections. The number of female candidates is always much lower than the number of male ones, especially when we take into account the proportions of both sexes in the contemporary Polish society. Electoral committees, very often associated with parties, are not actually bodies of authority in the strict sense of this word, but they exercise very important public functions. Their approval is required for anyone wishing to become a candidate in multi-seat constituencies." 30

Prof. Krzysztof Skotnicki was among those who claimed that the bill is not in accordance with the constitutional principle of equality and it violates the freedom of political parties. ${ }^{31}$

There are also critical views of parities, even among women. "Nelly Rokita from PiS (Law and Justice) lambasts the idea of gender parity and adds that one should not persuade women to vote for other women. This restricts their freedom of choice. (...) There are no good women's organizations without men. We need them to solve every single problem." ${ }^{32}$

Parities have also been criticized by dr. Barbara Fedyszak-Radziejowska and Krystyna Mokrosińska. ${ }^{33}$ The Government Plenipotentiary for Equal Treatment, Elżbieta Radziszewska is also against the constitutional regulation of gender parity. According to Radziszewska, it is political parties that should implement internal solutions aiming at increasing the participation of women in politics. The minister would also like to introduce the gender index ${ }^{34}$ analysis, thanks to which differences between sexes will be eliminated, and women will more often hold managerial positions. As

29 www.kongreskobiet.pl.

30 P. Winczorek, Uchwalić i uchylić, "Polityka”, No. 11, March 13, 2010, p. 32.

31 A. Sijka, Seksmisja bez protezy, "Wprost", March 14, 2010, p. 23.

32 www.wiadomości.gazeta.pl, August 2, 2005.

33 www.wyborcza.pl, July 26, 2009.

34 Gender Index is based on monitoring and analysing a work environment in terms of the equality of men and women in seven principal area: recruitment, vocational training, promotions, remuneration, combining a professional career with a family life, protection against sexual harassment and mobbing, job loss protection. In Poland, Gender Index research has been done in about 300 companies in the years 2005-2008. 
Radziszewska indicates, "experiences of particular countries lead to a conclusion that constitutional parities, which have been introduced in five countries of the European Union (Belgium, France, Spain, Portugal, Slovenia), are not the most effective method of increasing the participation of women in politics. In France, with gender parity of 50\%, only 18\% of MPs are women, which is a lot less than in Poland. In Slovenia, the figure is 33\% - far below the Union aver." ${ }^{35}$

However, it must be mentioned here that in France, if a party fails to comply with the principle of gender parity, it may still take part in elections. It will only have to pay a financial penalty. Large party groups often deliberately violate the principle of parity and accept financial consequences in the hope that such tactics will bring them more political benefits. ${ }^{36}$

Elżbieta Radziszewska also argues that the regulation on parity is unconstitutional (the speaker of the Sejm Bronisław Komorowski, who is now the President of Poland, expressed similar doubts). She quotes the French constitutional court's ruling, which recognized the need for making such amendments to the constitution which would facilitate the introduction of quota systems. The originators of the gender parity bill indicate, however, that Spain introduced the same solutions without changing its constitution as the Spanish Constitutional Tribunal ruled that they are in accordance with the fundamental law. ${ }^{37}$

Some authors argue that in the countries where women have the biggest parliamentary representation, there are no constitutional gender parities. ${ }^{38}$

The opponents of the gender parity bill formed the Citizens' Movement for Defending Democracy against Parities. The movement issued an open letter, signed by, among others, prof. Jadwiga Staniszkis and Krystyna Mokrosińska. The followers of this initiative claim that the idea of gender parities discriminates women. They believe that better education could

35 www.iwoman.pl, October 6, 2009, see also: M. Fuszara, Kobiety, mężczyźni, parytet, "Analizy i Opinie“, No. 9, (Warszawa 2009 ISP).

36 For more details see: A. Grabau, Parytet niejedno ma imię..., p. 32.

37 www.kongreskobiet.pl.

38 A. Sijka, Seksmisja bez protezy..., p. 23. 
bring much better results. Jadwiga Staniszkis even argues that "parities will affect the power and superiority of women. (...) Facilitations weaken the sense of winning." 39

It should also be emphasized that the Bureau of Research of the Polish Sejm has analysed parity solutions in the whole world. The results show that in 16 countries such guarantees are of constitutional character, whereas in 47 countries the regulations are included in electoral laws. In another 69 countries they are introduced in the statutes of political parties.

On September 10, 2009, the secretariat of the Speaker of the Polish Sejm received a document notifying that the Citizens' Committee for the legislative initiative Czas na kobiety ("Time for Women") had been established. Its purpose was to collect 100,000 signatures under the gender parity bill. ${ }^{40}$

\section{THE REPRODUCTION OF THE CITIZENS' COMMITTEE'S OPEN LETTER}

The Citizens' Committee for the legislative initiative Czas na kobiety ("Time for Women") offering its support to the bill on changing the law - the act of the electoral law to the Sejm and the Senate, district councils, county councils and regional councils, and the act of the electoral law to the European Parliament, with regard to the introduction of gender parity on electoral lists.

39 K. Janowska, Portret antybohaterki, an interview with prof. Jadwiga Staniszkis, "Przekrój”, No. 11, March 16, 2010.

40 A. Sijka, Seksmisja bez protezy..., p. 23. 
The address of the committee "Czas na kobiety" ul. Noakowskiego $4 / 8$

00-666 Warszawa

To Bronisław Komorowski

The Speaker of the Polish Sejm

Ul. Wiejska $4 / 6 / 8$

00-902 Warszawa

Dear Mr Speaker,

We would like to notify you that the Citizens' Committee for the legislative initiative "Czas na kobiety" has been established. The committee supports the bill on changing the law - the act of the electoral law to the Sejm and the Senate, district councils, county councils and regional councils, and the act of the electoral law to the European Parliament, with regard to the introduction of gender parity on electoral lists.

The Committee Czas na kobiety is based in Warsaw at Noakowskiego 4/8. It is composed of 23 Polish citizens who have the right to vote in parliamentary elections and who have declared their willingness to join the Committee in writing.

We would also like to inform you that Mr Jacek Ambroziak has been appointed the Committee's plenipotentiary and Mrs Magdalena Fuszara has been appointed his deputy.

Please find enclosed the bill on changing the law - the act of the electoral law to the Sejm and the Senate, district councils, county councils and regional councils, and the act of the electoral law to the European Parliament, with regard to the introduction of gender parity on electoral lists.

The Bureau of the Congress of Polish Women e-mail: biuro@kongreskobiet.pl 
The participation of women in politics. Deliberations on the gender parity bill... 101

It must be reminded here that the bill on changing the law - "the act of the electoral law to the Sejm and the Senate, district councils, county councils and regional councils, and the act of the electoral law to the European Parliament, with regard to the introduction of gender parity on electoral lists" - was prepared as the result of the resolutions made at the Congress of Polish Women in July 2009.

The new act is to change three electoral laws - to the Sejm, to the European Parliament, and to the councils of districts, counties and voivodeships. Gender parity does not extend to the elections to the Senate and the councils of districts inhabited by fewer than 20,000 people as they have the plurality voting system. The bill specifies that the number of women on electoral lists cannot be lower than the number of men. 50\% gender parity is one of the principal assumptions of the act.

In the introduction to the bill, its authors point that the new act is intended to "ensure more efficient implementation of the principle of equality of women and men in all spheres of life, which is expressed in article 33 of the Constitution of Poland, and to guarantee that women have the same chance as men when they apply for the seats in the bodies of public authority, chosen in general elections."

In accordance with article 1 of the proposed bill, some amendments should be made to the act of April 12, 2001, Electoral law to the Sejm and the Senate of the Republic of Poland. ${ }^{41}$ A new paragraph 2a should be added to art. 143 par. 2. It will specify that "the number of women on a district list cannot be lower than the number of men." The new text of art. 146 par. 1 after the amendments proposed by the bill is as follows:

"When a district electoral commission receives a list for registration, it examines, in the presence of a person who submitted the list, whether it meets the requirements specified in art. 143 par. 21 and art. 144, and hands a person submitting the list an approval of registration in writing. The specimen of the approval will be specified by the National Electoral Commission."

41 Journal of Laws from 2007, No. 190, item 1360. 
The bill prepared by the Congress of Polish Women also introduces changes in the act of July 16, 1998 - The electoral law to district councils, county councils and regional councils ${ }^{42}$ (art. 2 of the proposal). Pursuant to this, a new paragraph $2 \mathrm{a}$ will be added to art. 98 par. 2. It says:

"The number of women on a list cannot be lower than the number of men. This principle is not applied in the case of complementary elections to the council of a district inhabited by fewer than 20,000 people."

The bill under discussion also makes amendments to two articles in the act of January 23, 2004 - The electoral law to the European Parliament. ${ }^{43}$ Thus, paragraph $2 \mathrm{a}$ is added to art. 59 par. 2. It says:

2.a The number of women on a district list cannot be lower than the number of men". In turn, art. 65 par. 1 of the electoral law to the European Parliament specifies:

1. "When a district electoral commission receives a list for registration, it examines, in the presence of a person who submitted the list, whether it meets the requirements specified in art. 59 par. 2a and art. 64, and hands a person submitting the list an approval of registration in writing. The specimen of the approval will be specified by the National Electoral Commission."

In the justification of the bill, its authors wrote that the proposed changes in the electoral law should be introduced through the constitution because the number of women on electoral lists is disproportionately low in relation to the number of female voters, their intellectual abilities and moral potential. Women should be encouraged to actively participate in elections. We must also remind party leaders that women should be taken into account when preparing electoral lists. The authors of the proposal also emphasize that we can no longer ignore the fact that, although women

42 Journal of Laws from 2003, No. 159, item 1547.

43 Journal of Laws from 2004, No. 25, item 219. 
account for the majority of citizens, they still have a minority share in the bodies of state authority. This results from the established Polish customs and tradition which locate women at the lower tiers of the hierarchy of power. The originators of the gender parity bill recognize the need for changing this situation, and believe that only new legal regulations will help to achieve this. They also point that the proposed bill does not indicate who one should vote for. It only aims at ensuring that a certain proportion of women will appear on party lists. The act does not also specify the order in which the names should be placed on the lists. Finally, the followers of the bill emphasize that the new regulation does not guarantee that women will be elected. However, it does increase their chances. ${ }^{44}$

After the required number of signatures had been collected, on January 20, 2010, the bill was submitted to the Speaker of the Sejm Bronisław Komorowski for the first reading. At the first session of the Sejm on February 18,2010 , the bill was sent to the ad hoc committee for examining some bills from the area of electoral law. ${ }^{45}$

The bill received a positive opinion from the experts in the Bureau of Research of the Polish Sejm. They concluded that the subject matter of the bill introducing gender parity on electoral lists is not covered by the rules of law. However, it must be assumed that "the bill is in accordance with the documents, which are not legally binding for Poland, and which specify the European Union's policy aimed at ensuring the bigger participation of women in public life." 46

Why are women not willing to vote for other women? It is not just the matter of parity, where women find it difficult to fight their way through male-dominated organizations. It is also not the matter of very few

44 For more details see: justification of the gender parity bill.

45 www.sejm.gov.pl.

46 A legal opinion on the accordance with of the bill on changing the law with the constitution - "the act of the electoral law to the Sejm and the Senate, district councils, county councils and regional councils, and the act of the electoral law to the European Parliament, with regard to the introduction of gender parity on electoral lists." BASWAL-48/10 from January 25, 2010. 
women's names on electoral lists, which, incidentally, are typically placed at the bottom of party lists as the first positions are occupied by men. It is also not a psychological issue as we do not like to be managed by women and we treat them as rivals. Joanna Szymanek-Deresz, who was an MP from the Democratic Left Alliance (SLD), emphasized that "there are also some subtle issues, such as the Catholic Church's attitude to women (a woman should take care of her household rather than get involved in politics) as well as political infantilism presented by some ladies, which affects the way we are perceived by voters."

Prof. Fuszara also indicates that mass media do not help to change the stereotypical view of a woman's role in the society - as a housekeeper, taking care of children. As the analysis of television programmes shows, $90 \%$ of broadcasting time is devoted to male politicians. Their female colleagues have only $10 \%$ of the time in a campaign to present their views and a political programme.

Are women aware of the opportunities they have? There is a lot to do and make up for in this respect. It is perfectly evident in the example of the Democratic Left Alliance, the status of which specifies that the party has to guarantee $30 \%$ of the places on the electoral lists for women. ${ }^{47}$ The reality shows, however, how difficult it is to meet this requirement - there are only a few female politicians and not many women declare their willingness to take active part in politics. While they are able to work efficiently and passionately on the level of local governments, they encounter a psychological barrier when they start to think about politics on a larger scale. They lack faith in their own strength and abilities, support from their family and help from active male politicians.

There is also something in the nature of women that most of them prefer to work with women and are reluctant to be subordinate to a female boss. This thesis is proved by the survey results.

47 This principle was introduced by three parties: the Democratic Left Alliance (SLD), the Labour Union (UP) and the Freedom Union (UW). Similarly, the Green Party applies the principle of gender parity when it creates its list. It adopts the so called zip system, in which names of men and women on a list are placed alternately. For more details see: G. Basiak, M. Tkacz-Janik, Parytet dla Polek, www.krytykapolityczna.pl. 
The participation of women in politics. Deliberations on the gender parity bill... 105

\begin{tabular}{|l|c|c|c|c|}
\hline \multirow{2}{*}{$\begin{array}{l}\text { Having experience } \\
\text { in work with: }\end{array}$} & \multicolumn{4}{|c|}{ Would you personally prefer to cooperate with women or } \\
men?
\end{tabular}

Source: J. Szczepańska, Opinia społeczna o sytuacji kobiet $w$ Polsce, CBOS, “Opinie i diagnozy," No. 6, Warszawa 2007, p. 54.

\begin{tabular}{|l|l|l|l|l|l|l|l|l|l|l|}
\hline \multirow{2}{*}{$\begin{array}{l}\text { Would you personally } \\
\text { prefer to cooperate } \\
\text { with women or men? }\end{array}$} & \multicolumn{3}{|c|}{ Men's replies } & \multicolumn{7}{c|}{ Women's replies } \\
\cline { 2 - 11 } & 1992 & 1998 & 2003 & 2006 & 1992 & 1998 & 2003 & 2006 \\
\hline A woman & 11 & 7 & 13 & 8 & 14 & 12 & 11 & 9 \\
\hline A man & 48 & 43 & 33 & 41 & 46 & 40 & 40 & 37 \\
\hline It does not matter & 36 & 47 & 49 & 49 & 33 & 42 & 42 & 49 \\
\hline It is difficult to stay & 4 & 3 & 5 & 2 & 7 & 5 & 7 & 4 \\
\hline
\end{tabular}

Source: J. Szczepańska, Opinia społeczna o sytuacji kobiet w Polsce, CBOS, “Opinie i diagnozy," No. 6, Warszawa 2007, p. 57.

\begin{tabular}{|l|l|l|l|l|l|l|l|}
\hline \multirow{2}{*}{$\begin{array}{l}\text { Would you personally } \\
\text { prefer to cooperate with } \\
\text { women or men? }\end{array}$} & \multicolumn{2}{|c|}{$\begin{array}{c}\text { Replies of all re- } \\
\text { spondents }\end{array}$} & \multicolumn{2}{|c|}{ Men's replies } & \multicolumn{2}{c|}{ Women's replies } \\
\cline { 2 - 8 } & 1998 & 2006 & 1998 & 2006 & 1998 & 2006 \\
\cline { 2 - 9 } & \multicolumn{7}{|c|}{ in \% } \\
\hline With women & 12 & 11 & 9 & 10 & 17 & 12 \\
\hline With men & 28 & 25 & 31 & 25 & 24 & 25 \\
\hline Both with women and men & 18 & 19 & 18 & 16 & 18 & 22 \\
\hline It does not matter. & 39 & 43 & 40 & 48 & 38 & 38 \\
\hline
\end{tabular}

The reply "it is difficult to say" has been omitted.

Source: J. Szczepańska, Opinia społeczna o sytuacji kobiet w Polsce, CBOS, “Opinie i diagnozy," No. 6, Warszawa 2007, p. 57. 
TABLE 2. Who would you rather work for: a man or a woman and why?

\begin{tabular}{|c|c|c|}
\hline \multirow{2}{*}{$\begin{array}{l}\text { Replies of those people for whom the sex } \\
\text { of their co-workers is important }\end{array}$} & $\begin{array}{c}1998 \\
\text { (632 respondents) } \\
\end{array}$ & $\begin{array}{c}2006 \\
\text { (518 respondents) }\end{array}$ \\
\hline & \multicolumn{2}{|c|}{ in $\%$} \\
\hline \multicolumn{3}{|c|}{ Why would you rather cooperate with women? } \\
\hline $\begin{array}{l}\text { Interpersonal relations: women are easier to communicate with, } \\
\text { I feel better in the company of women, we have common subjects, } \\
\text { the atmosphere at work is nicer, and work is more interesting. }\end{array}$ & 15 & 14 \\
\hline $\begin{array}{l}\text { Being used to the cooperation with women or having no expe- } \\
\text { rience in the collaboration with men. }\end{array}$ & 2 & 4 \\
\hline $\begin{array}{l}\text { Because of the positive characteristics typically attributed to wo- } \\
\text { men: they are nice, helpful, tolerant and prudent. }\end{array}$ & 3 & 3 \\
\hline $\begin{array}{l}\text { Because of the positive professional traits typically attributed to } \\
\text { women: they are intelligent, ambitious, well-organized, sensible } \\
\text { and hard-working. }\end{array}$ & 1 & 1 \\
\hline $\begin{array}{l}\text { Because of the negative characteristics typically attributed to men: } \\
\text { drunkenness, untidiness, unreliability. }\end{array}$ & 1 & 1 \\
\hline \multicolumn{3}{|c|}{ Why would you rather cooperate with men? } \\
\hline $\begin{array}{l}\text { Interpersonal relations: men are easier to communicate with and } \\
\text { to collaborate with. }\end{array}$ & 16 & 17 \\
\hline $\begin{array}{l}\text { Because of the positive characteristics typically attributed to men: } \\
\text { they are not petty and combative, they are not easily influenced, } \\
\text { they don't gossip, they are more tolerant and resolute. }\end{array}$ & 14 & 13 \\
\hline $\begin{array}{l}\text { Because of the negative characteristics typically attributed to wo- } \\
\text { men: they are envious, malicious, catty, meticulous, they tend to } \\
\text { backbite and scheme against other people. }\end{array}$ & 8 & 8 \\
\hline $\begin{array}{l}\text { Because of the positive professional traits typically attributed to } \\
\text { men: they are more disciplined, better-organized, helpful, dyna- } \\
\text { mic, obedient, intelligent, competent and responsible. }\end{array}$ & 6 & 7 \\
\hline The respondent's job done exclusively (mostly) by men. & 10 & 4 \\
\hline $\begin{array}{l}\text { Being used to the cooperation with men or having no experience } \\
\text { in the collaboration with women. }\end{array}$ & 3 & 2 \\
\hline \multicolumn{3}{|c|}{ Why would you like to work both with women and men? } \\
\hline $\begin{array}{l}\text { Interpersonal relations: this is fun, the atmosphere is much } \\
\text { nicer, work is more interesting, and the balance is maintained. }\end{array}$ & 10 & 13 \\
\hline
\end{tabular}


The participation of women in politics. Deliberations on the gender parity bill... 107

\begin{tabular}{|l|c|c|}
\hline \multirow{2}{*}{$\begin{array}{l}\text { Replies of those people for whom the sex } \\
\text { of their co-workers is important }\end{array}$} & $\begin{array}{c}1998 \\
\text { (632 respondents) }\end{array}$ & $\begin{array}{c}2006 \\
\text { (518 respondents) }\end{array}$ \\
\cline { 2 - 4 } in \% \\
\hline $\begin{array}{l}\text { A gender is not important: what really matters is professional } \\
\text { qualifications. }\end{array}$ & 9 & 12 \\
\hline $\begin{array}{l}\text { Professional benefits resulting from working with the represen- } \\
\text { tatives of both sexes: work is more efficient, we can learn more } \\
\text { from people of both sexes. }\end{array}$ & 5 & 3 \\
\hline Being used to the cooperation both with women and men. & 3 & 2 \\
\hline Because of equal rights, equal qualifications of women and men. & 2 & 2 \\
\hline
\end{tabular}

Source: J. Szczepańska, Opinia społeczna o sytuacji kobiet w Polsce, CBOS, “Opinie i diagnozy," No. 6, Warszawa 2007, p. 55.

To end this topic, we must emphasize that even the followers of the gender parity bill do not treat this solution as the "permanent," optimal one. They propose that we should observe how it will work during the next two or three terms of office of Parliament and the elections to local governments. Prof. Winczorek notes that "if it turns out that the number of female candidates keeps increasing significantly and they are consistently entered as candidates by electoral committees, the act should be repealed as it would mean it has successfully changed our political reality." 48

To conclude, it is worth reminding that eleven years ago Poland was placed on the $42^{\text {nd }}$ position in the world in the rankings of women's activity (13\% of MPs were women). At present, we occupy the $64^{\text {th }}$ position in the world ( $20 \%$ of parliamentary seats are held by women). As it was mentioned before, the situation in the European Parliament looks even worse. Experts indicate that the world has moved forward, whereas we are staying behind. Therefore, we should give some thought to the possible reasons for this situation. After all, Poland, as it was noted before, belonged to the countries that were the first in Europe to grant suffrage to women. The problem of the underrepresentation of women had been steadily growing and in the year of our accession to the European Union we were already far behind the rest of Europe in the rankings. ${ }^{49}$

48 P. Winczorek, Uchwalić i uchylić..., p. 34.

49 For more details see: A. Grabau, Parytet niejedno ma imię..., pp. 32-33. 
TABLE 3. The number of women in the public sphere in comparison to Norway (in \%)

\begin{tabular}{|l|c|c|}
\hline & Poland & Norway \\
\hline Women in parliament & 20 & 37 \\
\hline Government members & 7 & 42 \\
\hline Women in the councils of local governments & 13 & 42 \\
\hline Government institutions & 16 & 41 \\
\hline Women in city councils & 18 & 34 \\
\hline
\end{tabular}

Source: J. Kowalska, Królestwo kobiet, "Newsweek" (Polish ed.), April 26, 2004, p. 38.

The opponents of parity in the electoral law emphasize that this issue should not be legally regulated. Stereotypes should be changed by means of education. The experiences of other countries show, however, that this simple solution may turn out to be ineffective. As Mika Larsson ${ }^{50}$ notes, on the basis of Swedish practice, "but for internal regulations, it would have been impossible to achieve such results. Even a country with seemingly ideal gender equality may not appear friendly in every situation." ${ }^{1}$

The question arises as to why Polish politics is such an unfriendly environment for women? Why is it that women do not hold positions, which involve key decision-making? It is a general rule that - as J. Paradowska indicates - Mr Minister manages and Ms woman does all the work, women either take the side-line seats or they adopt a role of party leaders' soldiers. It would be unfair to say that the reason for the male dominance in the electable bodies of authority is the fact that women themselves are reluctant to hold important positions and they lack serious professional ambitions. ${ }^{52}$ According to prof. M. Fuszara, the main reasons include:

- patronizing approach,

- oversimplification, belittling the role of women,

- disrespectful attitude

- paying pseudo-compliments,

50 A Swedish journalist and a former cultural attaché in Warsaw.

51 A. Grabau, Parytet niejedno ma imię..., p. 33.

52 J. Paradowska, Panie prosza panów..., p. 13. 
- pseudo-protective embracing,

- pseudo-friendly advising, etc.

Prof. Radosław Markowski carried out an experiment, modelled on the one performed in the USA back in the 1950s. ${ }^{53}$ Markowski analysed women's solidarity. He read descriptions of two candidates to female students, adding that one of them was a woman, and the other one was a man. Given the same set of personal characteristics, it was always the male candidate that emerged victorious. ${ }^{54}$

Politics is a difficult and often ruthless game and women do not like brutality. It is also difficult for them to reconcile their private life, household chores and upbringing children with a professional career. That is why, like in a Jewish joke, the women active in politics are those whose dog has died and the children have left home. It must also be remembered that, as Leon Petrażycki noted, "the elimination of legal barriers will not lead to de facto equal access of women and men to the public sphere." ${ }^{55}$

Grassroots work is required here. Polish women are not yet accustomed to seeing a woman on the position of authority. Even if they do notice it, only a few of them accept it. There still a long way to go before we manage to change the stereotypical view of a traditional role of women in public life. However, in order to do so we need integrity and loyalty. ${ }^{56}$

53 During the experiment the students were shown the texts. The researcher informed them that one article had been written by a woman and the other one by a man. Almost $70 \%$ of the students preferred the man's text.

54 A. Sijka, Seksmisja bez protezy..., p.23.

55 L. Petrażycki, O prawach kobiet, [in:] O nauce, prawie i moralności. Pisma wybrane, Warszawa 1985, p. 375.

56 Monika Płatek, www.psep.pl, November 2009. 